\title{
AMOT wt Allele
}

National Cancer Institute

\section{Source}

National Cancer Institute. AMOT wt Allele. NCI Thesaurus. Code C98144.

Human AMOT wild-type allele is located in the vicinity of Xq23 and is approximately $66 \mathrm{~kb}$

in length. This allele, which encodes angiomotin protein, is involved in the regulation of tight junction formation. 